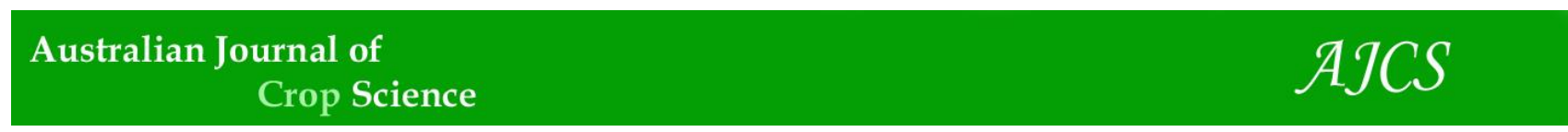

AJCS 11(09):1176-1180 (2017)

ISSN:1835-2707

doi: 10.21475/ajcs.17.11.09.pne530

\title{
Induction of resistance to fall armyworm (Spodoptera frugiperda) (Lepidoptera: Noctuidae) in transgenic and conventional corn plants
}

\author{
Marcos Felipe de Castro Lourençoㄹ, Alexandre José Rosa ${ }^{1}$, Ana Paula Silva Siqueira ${ }^{2}$, Lucas da Silva \\ Araujo $^{1}$, André Cirilo de Sousa Almeida ${ }^{*}$, Flávio Gonçalves de Jesus ${ }^{1}$, Paulo César Ribeiro da Cunha ${ }^{1}$ \\ ${ }^{1}$ Instituto Federal de Educação e Tecnologia Goiano -Campus Urutaí (IFGoiano), Rodovia Geraldo Silva \\ Nascimento, km 2,5, Zona Rural, Urutaí, GO. CEP: 75790-000, Brazil \\ ${ }^{2}$ Instituto Federal de Educação e Tecnologia Goiano -Campus Morrinhos (IFGoiano), Rodovia BR 153, km 633, \\ Zona Rural, Morrinhos, GO. CEP: 75650-000, Brazil
}

*Corresponding author: andre_cirillo@hotmail.com

\begin{abstract}
The fall armyworm (Spodoptera frugiperda) is an important pest of corn in Brazil. Insecticides are applied to reduce the losses caused by this pest. Integrated control methods, including resistance induction in plants using silicon and transgenic hybrids, must be used to reduce the impacts caused by insecticide application. The aim of this study was to assess the effects of calcium silicate application $\left(\mathrm{CaSi}_{4}\right)$ to the sowing furrow on $S$. frugiperda damage to and incidence on conventional and transgenic genotypes with different $B t$ technologies. The treatments were arranged in a randomized block design in a $3 \times 4 \times 4$ factorial scheme with three corn hybrids, Morgan 30A91 PRO Power Core ${ }^{\circledR}$ (Cry1F, Cry1A105, Cry2Ab2 Bt toxin), Morgan 20A55 Herculex ${ }^{\circledR}$ (Cry1F Bt toxin) and AG 1051 (conventional); four silicon doses, $0,300,600$ and $900 \mathrm{~kg}^{-\mathrm{ha}^{-1}}$ calcium and magnesium silicate (Agrosilicio Plus ${ }^{\circledR}, \mathrm{Ca}=$ $25 \%, \mathrm{Mg}=6 \%, \mathrm{Si}=10.5 \%$ ); and four assessment times, 15, 30, 45 and 60 days after emergence (DAE). Four replicates were performed. The mean number of caterpillars per plant, damage caused by $S$. frugiperda, and production components were assessed. Calcium and magnesium silicate application induced resistance in corn plants, thus reducing the damage caused by $S$. frugiperda. Corn responded to resistance induction with increasing doses of calcium and magnesium silicate. The transgenic hybrid with three proteins (Morgan 30A91 PRO) improved protection against S. frugiperda. The interaction between silicate fertilization and transgenics produced a synergistic effect, suggesting a viable alternative for $S$. frugiperda control.
\end{abstract}

Keywords: Silicate fertilization, integrated pest management, transgenic maize, Zea mays.

\section{Introduction}

Corn (Zea mays L.) is a tropical plant that requires heat and humidity for satisfactory production and rewarding yields as well as the interaction of a set of edaphoclimatic factors for proper growth. Despite its high production potential, corn is highly sensitive to biotic and abiotic stresses. Therefore, its cultivation requires planning and strict management (Andrade, 1995; Fancelli and Dourado Neto, 2004; Cruz et al., 2008). The fall armyworm (Spodoptera frugiperda) is a polyphagous species that attacks various economically important crops in several countries (Lopes et al., 2008; Aguirre et al., 2016). In Brazil, the fall armyworm is considered a key pest of corn because it causes enormous losses that can reduce production by more than $25 \%$. The adults have a high dispersion capacity and can produce several generations per year (Waquil \& Vilella, 2003).

Insecticides are applied to reduce the losses caused by this pest. The frequent use of this control method may impacts humans, the environment, the selection of resistant insects, and the resurgence of pests, in addition to leaving residues in food (Sosa-Gomez \& Solva, 2010). The use of integrated control methods, including resistance induction in plants using silicon and transgenic hybrids, is necessary to reduce the impacts of insecticide application (Blanco et al., 2016; Reynolds et al., 2016). The use of transgenic corn plants expressing Bacillus thuringiensis (Bt) insecticidal proteins is one of the main alternatives for fall armyworm control in Brazil, reaching $80 \%$ of the planted area (Omoto et al., 2016). In the current corn production system in Brazil, multiple cropping with some $B t$ crops and the non-implementation of refuge areas have contributed to the evolution of resistance to $B t$ corn plants in the fall armyworm population (Farias et al., 2014; Horkoshi et al., 2016). Fall armyworm resistance to the Cry1F Bt protein has already been reported in Brazil (Farias et al., 2014).

The application of specific nutrients, including silicon, induces plant defenses against pests. Defense is induced in plants due to the formation of passive or active mechanical barriers by altering the plant biochemical responses to herbivore attack (Epstein, 1994; Marschner, 1995). Silicon application may reduce the population growth rate of the pest, increase caterpillar mortality, and stimulate growth and plant production through indirect effects possibly related to the presence of defense substances, which may have adverse effects on the insect's biology and behavior (Goussain et al., 2002; Gomes et al., 2005; Antunes, 2010).

Given the constant imbalances in Bt-corn fields and the benefits of applying nutrients such as silicon, plant resistance induction may be an alternative to delay the evolution of resistance to $B t$ corn in the fall armyworm. Accordingly, this study was conducted to assess the effects of calcium silicate 
application to the sowing furrow on S. frugiperda damage to and incidence on conventional and transgenic corn genotypes with different $B t$ technologies.

\section{Results and Discussion}

The damage caused by $S$. frugiperda was affected by the time, hybrid and silicate dose. Significant interactions were observed between the factors of time and hybrid and between silicate dose and hybrid. The hybrids significantly differed from each other in the number of $S$. frugiperda, and a significant interaction was observed between silicate dose and hybrid (Table 1).

The damage caused by $S$. frugiperda caterpillars was highest at 30 DAE (3.84), and the conventional hybrid AG 1051 was the most damaged, followed by Morgan 20A55 (Herculex) and Morgan 30A91 PRO (Power Core). These results are attributable to the presence of genes of $B$. thuringiensis bacteria with insecticidal activity against $S$. frugiperda (Moraes et al., 2015).

A significant response to the silicon doses was observed, and the damage caused by $S$. frugiperda decreased with increasing silicate dose. This decrease in damage caused by S. frugiperda resulted from the formation of a protective silicon layer in leaves, which acted as a mechanical barrier impairing caterpillar feeding (Goussain et al., 2002; Keeping $\&$ Kevedaras 2008). The number of $S$. frugiperda caterpillars was higher in the conventional hybrids AG 1051 and Morgan 20A55 (Herculex) than in the Morgan 30A91 PRO (Power Core) hybrid. The Morgan 30A91 PRO hybrid has three $B t$ proteins (Cry1F, Cry1A105, Cry2Ab2), whereas the Morgan 20A55 hybrid has only the Cry1F Bt protein. Bt protein pyramiding achieves better results in $S$. frugiperda control compared with a hybrid expressing the Cry1F protein as the only Bt protein (Farias et al., 2016); susceptibility of the latter type of hybrids to $S$. frugiperda has been reported (Farias et al., 2014; Bernardi et al., 2015). This explains why the performance of this hybrid is similar to that of a conventional hybrid.

A significant interaction between time and corn hybrid was observed for damage caused by S. frugiperda (Figure 1). The conventional hybrid AG 1051 exhibited more damage than the transgenic hybrids, with the highest values from 30 to 45 DAE. The corn hybrids exhibited a decreasing linear response to the doses of calcium and magnesium silicate (Figure 2). S. frugiperda damage decreased with increasing dose due to silicon accumulation in the plants, which caused the caterpillars to feed less on the plants that received the highest doses. Corn is a silicon-accumulating plant (Andrade et al., 2014), and this chemical element is associated with induction of plant resistance to pest attacks (Souza et al., 2014; Almeida et al., 2015, Nikpay et al., 2015). Silicon application in corn plants increases $S$. frugiperda larval mortality, caterpillar cannibalism and mandible wear from plant feeding (Goussain et al., 2002).

The number of caterpillars remained constant in the Morgan 20A55 (Herculex) hybrid with increasing silicate dose, whereas the increasing dose reduced the number of $S$. frugiperda caterpillars in the conventional hybrid AG 1051 (Figure 3). This decrease in the number of caterpillars in the conventional hybrid indicates plant resistance induction due to the application of a silicon source and suggests an alternative for $S$. frugiperda control and/or a control alternative in the refuge area in corn to disfavor the selection of pest resistance to Bt organisms (Zancanaro et al., 2012; Horkoshi et al., 2016).
The hybrids exhibited significant differences in ED, NRPE, NGPR, and 100W. The calcium and magnesium silicate doses affected EL and NGPR (Table 2).

The corn hybrids exhibited significant differences in dry phytomass, yield and stand (Table 3). Only yield differed significantly with increasing silicon dose, with no interaction between the factors of hybrid and dose. Yield was higher in the transgenic hybrids than in the conventional hybrids, and the calcium and magnesium silicate dose of $600 \mathrm{~kg}^{-h^{-1}}$ increased the yield. These data further support resistance induction and the use of transgenic hybrids for $S$. frugiperda control, as the grain yield increased with increasing dose. Corn plant yield also increased with increasing silicon dose. This increase in yield was related to the increase in plant chlorophyll content and number of chloroplasts upon silicate fertilization, which improved the photosynthetic efficiency and reduced the transpiration rate, thus avoiding water loss through the stomata. These changes may also alter the architecture of the plants, rendering them more upright and thus reducing self-shading (Ma \& Takahashi, 2002; Xie et al., 2014)

\section{Materials and Methods}

\section{Experimental conditions}

The experiment was conducted in the experimental area of the Federal Institute of Goiás (Instituto Federal Goiano) Urutaí Campus in the municipality of Urutaí, Goiás

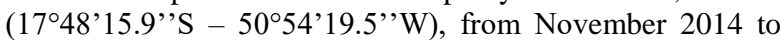
May 2015. The experimental area was managed for two years by rotation of corn in the spring/summer with millet in the autumn/winter. Before starting the experiment, soil samples were collected at a depth of 0 to $0.20 \mathrm{~m}$ for chemical and physical analysis. The soil (Red-Yellow Latosol) had the following physicochemical characteristics: $\mathrm{pH}$ in water: 5.5; $\mathrm{Ca}, \mathrm{Mg}, \mathrm{Al}, \mathrm{H}+\mathrm{Al}: \quad 2.3, \quad 0.8, \quad 0.0$ and $1.4 \mathrm{cmol} / \mathrm{dm}^{3}$, respectively; $\mathrm{K}$ and $\mathrm{P}: 141.0$ and $4.7 \mathrm{mg} / \mathrm{dm}^{3}$, according to the anion exchange resin method; organic matter: $18.0 \mathrm{~g} / \mathrm{dm}^{3}$; base saturation: $71.19 \%$; and texture: 35,12 and $53 \mathrm{~g} / \mathrm{kg}$ clay, silt and sand, respectively.

Pre-sowing management was conducted using a conventional system with one plowing and one harrowing. A total of 3.5 seeds were sown per linear meter, and $420 \mathrm{~kg} \mathrm{ha}^{-1}$ of fertilizer (10-29-20, NPK) was used in fertilization at planting. Topdressing with $120 \mathrm{~kg} \mathrm{ha}^{-1}$ nitrogen was applied at the V4-V5 stage.

\section{Treatments and assay}

The treatments were arranged in a randomized block design in a $3 \times 4 \times 4$ factorial scheme with three corn hybrids, Morgan 30A91 PRO Power Core ${ }^{\circledR}$ (Cry1F, Cry1A105, Cry2Ab2 Bt toxin), Morgan 20A55 Herculex ${ }^{\circledR}$ (Cry1F Bt toxin) and AG 1051 (conventional); four silicon doses, 0, 300, 600 and 900 kg. ha ${ }^{-1}$ calcium and magnesium silicate (Agrosilicio Plus ${ }^{\circledR}$, $\mathrm{Ca}=25 \%, \mathrm{Mg}=6 \%, \mathrm{Si}=10.5 \%)$; and four assessment times, 15, 30, 45 and 60 days after emergence (DAE). Four replicates were performed. The plots consisted of six rows $(0.5 \mathrm{~m}) 6 \mathrm{~m}$ in length with a total area of $18 \mathrm{~m}^{2}$. The four central rows of each plot were assessed, excluding $0.5 \mathrm{~m}$ from each end, resulting in a total useful area of $10 \mathrm{~m}^{2}$ per plot. The other cultivation practices were performed according to Francelli \& Dourado Neto (2004). 
Table 1. Effect of hybrids, time, and calcium and magnesium silicate dose on Spodoptera frugiperda (Lepidoptera: Noctuidae) damage to and mean number on corn.

\begin{tabular}{|c|c|c|}
\hline \multirow{2}{*}{ Factors $^{1}$} & \multicolumn{2}{|c|}{ Evaluation } \\
\hline & Damage to S.frugiperda & Number of S.frugiperda \\
\hline \multicolumn{3}{|l|}{ Time $(\mathrm{T})$} \\
\hline $15 \mathrm{DAE}$ & 2.96 & 1.00 \\
\hline $30 \mathrm{DAE}$ & 3.84 & 1.03 \\
\hline $45 \mathrm{DAE}$ & 3.82 & 1.08 \\
\hline $60 \mathrm{DAE}$ & 3.77 & $--^{2}$ \\
\hline Test $\mathrm{F}_{\text {time }}$ & $17.59^{* *}$ & $0.65^{\mathrm{ns}}$ \\
\hline \multicolumn{3}{|l|}{ Hybrids (H) } \\
\hline AG 1051 & $4.44^{\mathrm{a}}$ & $1.13^{\mathrm{a}}$ \\
\hline Morgan 20A55 & $4,11^{\mathrm{b}}$ & $1.11^{\mathrm{a}}$ \\
\hline Morgan 30A91 PRO & $2.23^{\mathrm{c}}$ & $0.88^{\mathrm{b}}$ \\
\hline Test $F_{\text {hybrids }}$ & $18.30^{* * *}$ & $8.76^{* * *}$ \\
\hline \multicolumn{3}{|l|}{ Silicate dose $(\mathrm{S})$} \\
\hline 0 & 5.04 & 1.14 \\
\hline 300 & 4.22 & 0.96 \\
\hline 600 & 3.10 & 1.00 \\
\hline 900 & 2.02 & 1.06 \\
\hline Test $F_{\text {silicate dise }}$ & $16.78^{* * *}$ & $2.13^{\mathrm{ns}}$ \\
\hline \multicolumn{3}{|l|}{ Interaction } \\
\hline Teste $\mathrm{F}_{(\mathrm{T} \times \mathrm{H})}$ & $2.7^{*}$ & $1.59^{\mathrm{ns}}$ \\
\hline Teste $\mathrm{F}_{(\mathrm{T} \times \mathrm{S})}$ & $1.15^{\mathrm{ns}}$ & $1.45^{\mathrm{ns}}$ \\
\hline Teste $\mathrm{F}_{(\mathrm{S} \times \mathrm{H})}$ & $7.77^{* *}$ & $2.27 *$ \\
\hline Teste $\mathrm{F}_{(\mathrm{T} \times \mathrm{H} \times \mathrm{S})}$ & $0.72^{\mathrm{ns}}$ & $1.12^{\mathrm{ns}}$ \\
\hline $\mathrm{CV}(\%)$ & 19.57 & 31.12 \\
\hline
\end{tabular}

${ }^{1}$ Means in the same column followed by the same letter do not differ according to the Tukey test at $5 \%$ probability $(\mathrm{P} \leq 0.05),{ }^{* *},{ }^{*},{ }^{\text {ns }}$ : significant at 1 and $5 \%$ probability and non-significant. ${ }^{2}$ insufficient number of insects in the plot

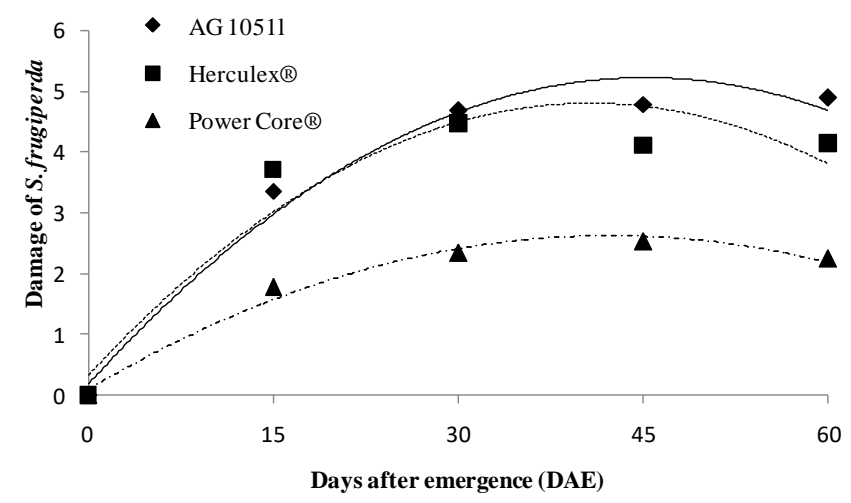

Fig 1. Spodoptera frugiperda (Lepidoptera: Noctuidae) damage in corn hybrids at different times. $\downarrow \mathrm{y}=-0.002 \mathrm{x}^{2}+0.222 \mathrm{x}+0.198$, $\mathrm{R}^{2}=0.98^{* *} ; \mathrm{y}=0.002 \mathrm{x}^{2}+0.22 \mathrm{x}+0.338, \mathrm{R}^{2}=0.919 ; \boldsymbol{\Delta} \mathrm{y}=0.001 \mathrm{x}^{2}+0.120 \mathrm{x}+0.091, \mathrm{R}^{2}=0.982$.

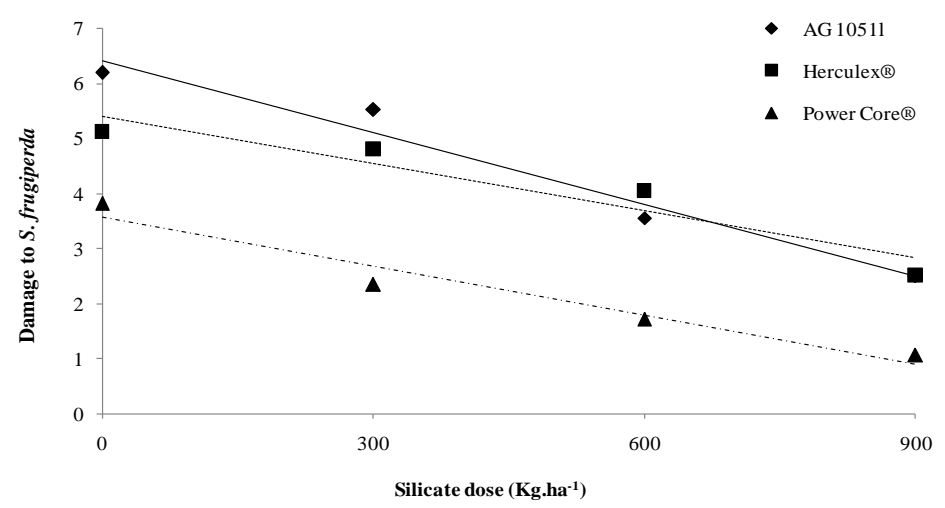

Fig 2. Spodoptera frugiperda (Lepidoptera: Noctuidae) damage in corn hybrids with different calcium and magnesium silicate doses according to the Davis scale. $\mathrm{y}=-0.004 \mathrm{x}=6.397, \mathrm{R}^{2}=0.97^{* * *} ; \mathrm{y}=0.002 \mathrm{x}=5.404+0.904, \mathrm{R}^{2}=0.90^{* * *} ; \boldsymbol{\Delta} \mathrm{y}=0.001 \mathrm{x}^{2}+0.120 \mathrm{x}+$ $0.091, \mathrm{R}^{2}=0.95^{* *}$. 
Table 2. Ear diameter (ED), ear length (EL), number of rows per ear (NRPE), number of grains per row (NGPR), and 100-grain weight $(100 \mathrm{~W})$ in corn hybrids with different calcium and magnesium silicate doses.

\begin{tabular}{|c|c|c|c|c|c|}
\hline Hybrids $(\mathrm{H})^{1}$ & ED & EL & NRPE & NGPR & $100 \mathrm{~W}$ \\
\hline AG 1051 & $36.45^{\mathrm{c}}$ & $15.47^{\mathrm{a}}$ & $13.23^{\mathrm{c}}$ & $26.53^{b}$ & $22.90^{\mathrm{b}}$ \\
\hline Morgan 20A55 & $47.47^{\mathrm{a}}$ & $15.00^{\mathrm{a}}$ & $17.73^{\mathrm{a}}$ & $30.74^{\mathrm{a}}$ & $26.43^{\mathrm{a}}$ \\
\hline Morgan 30A91 PRO & $42.15^{\mathrm{b}}$ & $14.60^{\mathrm{a}}$ & $15.45^{\mathrm{b}}$ & $28.56^{\mathrm{ab}}$ & $26.89^{\mathrm{a}}$ \\
\hline Teste $F_{\text {tecnologia }}$ & $8.57^{* *}$ & $0.94^{\mathrm{ns}}$ & $4.73^{* *}$ & $5.78^{* *}$ & $2.93^{*}$ \\
\hline \multicolumn{6}{|l|}{ Silicate doses (S) } \\
\hline 0 & 42.60 & 13.66 & 15.25 & 25.15 & 23.89 \\
\hline 300 & 42.75 & 14.53 & 16.10 & 27.92 & 24.86 \\
\hline 600 & 41.09 & 16.27 & 15.78 & 28.80 & 26.75 \\
\hline 900 & 41.65 & 18.63 & 14.88 & 30.57 & 26.99 \\
\hline Test F & $0.59^{\mathrm{ns}}$ & $5.01^{\text {*** }}$ & $1.98^{\mathrm{ns}}$ & $7.10^{* * *}$ & $0.87^{\mathrm{ns}}$ \\
\hline Test $F_{(G \times S)}$ & $0.48^{\mathrm{ns}}$ & $0.68^{\mathrm{ns}}$ & $1.24^{\mathrm{ns}}$ & $2.15^{\mathrm{ns}}$ & $1.76^{\mathrm{ns}}$ \\
\hline $\mathrm{CV}(\%)$ & 8.44 & 11.92 & 8.61 & 12.24 & 9.45 \\
\hline
\end{tabular}

Table 3. Dry phytomass, yield and stand for different hybrids and silicate doses and interaction between all factors.

\begin{tabular}{lccc}
\hline Hybrids $(\mathrm{H})^{1}$ & Dry phytomass $(\mathrm{g})$ & Yeld $\left(\mathrm{kg} \cdot \mathrm{ha}^{-1}\right)$ & Stand/ha \\
\hline AG 1051 & $208.53^{\mathrm{b}}$ & $6310.27^{\mathrm{b}}$ & $65718.75^{\mathrm{a}}$ \\
Morgan 20A55 & $243.27^{\mathrm{ab}}$ & $7982.90^{\mathrm{a}}$ & $65898.75^{\mathrm{a}}$ \\
Morgan 30A91 PRO & $231.96^{\mathrm{a}}$ & $7645.46^{\mathrm{a}}$ & $65937.50^{\mathrm{a}}$ \\
Teste F hibridos & 5.33 & 11.57 & 1.24 \\
\hline Silicate doses $(\mathrm{S})$ & & & 66665.50 \\
\hline 0 & 212.67 & 6039.97 & 66670.50 \\
300 & 232.89 & 6376.76 & 68083.60 \\
600 & 236.08 & 8798.08 & 65416.67 \\
900 & 241.98 & 8336.71 & $2.38^{\mathrm{ns}}$ \\
Test $\mathrm{F}_{\text {silicate doses }}$ & $1.42^{\mathrm{ns}}$ & $6.21^{* *}$ & $2.38^{\mathrm{ns}}$ \\
\hline Test $\mathrm{F}_{(\mathrm{H} \text { x }}$ & $0.51^{\mathrm{ns}}$ & $0.75^{\mathrm{ns}}$ & 2.44 \\
CV $(\%)$ & 13.47 & 13.56 & \\
\hline
\end{tabular}

${ }^{1}$ Means in the same column followed by the same letters do not differ according to the Tukey test at $5 \%$ probability $(\mathrm{P} \leq 0.05),{ }^{* *},{ }^{2},{ }^{\text {ns }}$ : significant at 1 and $5 \%$ probability and non-significant.

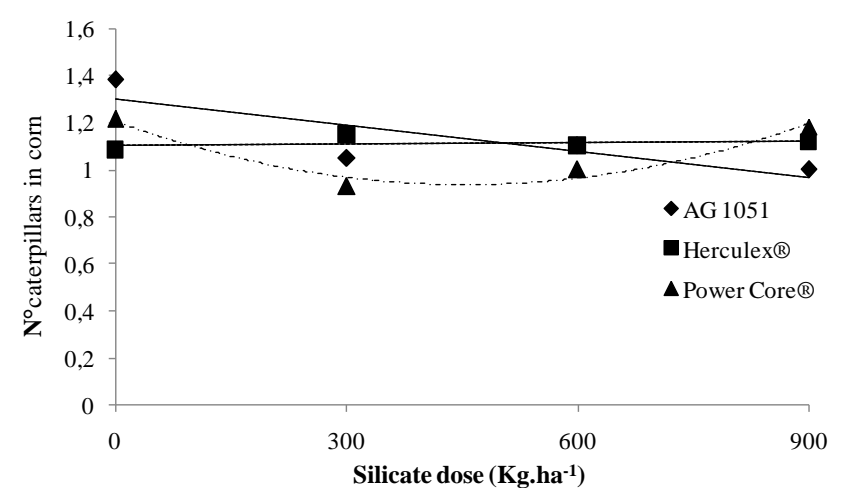

Fig 3. Number of Spodoptera frugiperda (Lepidoptera: Noctuidae) caterpillars in corn hybrids with different calcium and magnesium silicate doses. $\mathrm{y}=-0.000 \mathrm{x}+1.298, \mathrm{R}^{2}=0.685^{*} ; \mathrm{y}=2 \mathrm{E}-05 \mathrm{x}+1.104, \mathrm{R}^{2}=0.049^{\mathrm{ns}} ; \boldsymbol{\Delta} \mathrm{y}=1 \mathrm{E}-06 \mathrm{x}^{2}-0.001 \mathrm{x}+1.203, \mathrm{R}^{2}=0.949^{*}$

The mean number of caterpillars per plant and the damage caused by $S$. frugiperda were assessed (Davis, et. al, 1992). Each damage assessment was performed in triplicate. Grain yield was estimated based on the weight of grains harvested in the useful plot area and corrected to $13 \%$ moisture. Plants from 3 linear meters of useful area were collected and dried in a forced air oven (Model SP-102/2000) at $65^{\circ} \mathrm{C}$ for 72 hours to determine the phytomass. To assess the production parameters, 10 ears were randomly collected to measure ear length (EL) and diameter (ED), the number of rows per ear (NRPE), and the number of grains per row (NGPR). After threshing, 100 grains of corn were randomly collected to determine the weight $(100 \mathrm{~W})$.

\section{Statistical analysis}

The results were subjected to analysis of variance (ANOVA), and when significant, the means were compared using the Tukey test at $5 \%$ probability.

\section{Conclusion}

Calcium and magnesium silicate application induces resistance in corn plants, reducing the damage caused by $S$. frugiperda. Corn responds to resistance induction with increasing doses of calcium and magnesium silicate. The transgenic hybrid with three proteins (Morgan 30A91 PRO) 
provided the best protection against $S$. frugiperda. The interaction between silicate fertilization and transgenic hybrids resulted in a synergistic effect, which suggests that this combination is a viable alternative for $S$. frugiperda control.

\section{Acknowledgments}

The authors thank Instituto Federal Goiano - Campus Urutaí for funding the present study

\section{References}

Aguirre LA, Hernández-Juárez A, Flores M, Cerna E, Landeros J, Frías GA, Harris MK (2016) Evaluation of foliar damage by Spodoptera frugiperda (Lepidoptera: Noctuidae) to genetically modified corn (Poales: Poaceae) in Mexico. Flo Entomol. 99(2): 276-280.

Almeida ACS, Silva LP, Jesus FG, Nogueira L, Sousa Netto M, Cunha PCR (2014). Efeito de indutores de resistência em híbridos de milho na atratividade do pulgão Rhopalosiphum maidis (Fitch, 1856) (Hemiptera: Aphididae). Agrarian. 8(27): 23-29.

Andrade FA, Andrade Junior O, Andrade CGTJ, Migloranza E (2014) Accumulation of silicon and arrangement and

shapes of silica bodies in corn leaves. Gen Mol Res. 13(1): 1690-1696.

Andrade FH (1995) Analysis of growth and yeld of mayze, sunflower and soybean grown at Balcarce, Argentina. Field Crop Res. 41(1): 1-12.

Antunes CS, Moraes JC, Antônio A, Silva VF (2010) Influência da aplicação de silício na ocorrência de lagartas (LEPIDOPTERA) e de seus inimigos naturais chaves em milho (Zea mays L.) e em girassol (Helianthus annuus L.). Biosci J. 26(4): 619-625.

Bernardi D, Salmeron E, Horikoshi RJ, Bernardi O, Dourado PM, Carvalho RA, et al. (2015) Cross-Resistance between Cry1 Proteins in Fall Armyworm (Spodoptera frugiperda) May Affect the Durability of Current Pyramided Bt Maize Hybrids in Brazil. PLoS ONE. 10(10): e0140130.

Blanco CA, Chiaravalle W, Dalla-Rizza M, Farias JR, Garcia-Degano MF, Gastaminza G, Mota-Sânchez D, Maruia MG, Omoto C, Pieralis BK, Rodriguez J, Rodriguez-Maciel JC, Terán-Santofimio H, Terán-Vargas AP, Valencia SJ, Wilink E (2016) Current situation of pests targeted by Bt crops in Latin America. Curn Op Insc Scie. 15: 131-138.

Cruz SCS, Pereira FRS, Bicudo SJ, Albuquerque AW, Santos JR, Machado CG (2008) Nutrição do milho e da Brachiaria decumbens cultivado em consórcio em diferentes preparos do solo. Act Sci Agron. 30(5): 733-739.

Davis FM, Ng SS, Willians WP (1992) Visual rating scales for screening whorl-stage corn for resistance to fall armyworm. Mississippi: Agricultural and Forest Experiment Station, 9p. (Technical Bulletin, 186).

Epsten E (1994) The anomaly of silicon in plant biology. Proc Nat Acad Sci USA. .91:11-17.

Farias JR, Andow DA, Horikoshi RJ, Sorgatto RJ, Santos AC, Omoto C (2016) Dominance of Cry1F resistance in Spodoptera frugiperda (Lepidoptera: Noctuidae) on TC1507 Bt maize in Brazil. Pest Manag Sci 72: 974-979.

Farias JR, Horikoshi RJ, Santos AC, Omoto C (2014) Geographical and temporal variability in susceptibility to
Cry1F toxin from Bacillus thuringiensis in Spodoptera frugiperda (Lepidoptera: Noctuidae) populations in Brazil. J Econ Entomol. 107(6): 2182-2189.

Francelli AL, Dourado Neto D (2004) Produção de Milho $2^{\circ}$ ed. Piracicaba. 360p.

Gomes FB, Moraes JC, Santos CD, Goussain MM (2005) Resistance induction in wheat plants by silicon and aphids Sci Agic. 62(6): 547-551.

Goussain MM, Moraes JC, Carvalho JG, Nogueira NL, Rossi ML (2002) Efeito da aplicação de silício em plantas de milho no desenvolvimento biológico da lagarta-do-cartucho Spodoptera frugiperda (J. E. Smith) (Lepidoptera: Noctuidae). Neotrop Entomol. 31(2): 305-310.

Horkoshi RJ, Bernardi D, Bernardi O, Malaquias JB, Okuma DM, Miraldo LL, Amaral FSA, Omoto C (2016) Effective dominance of resistance of Spodoptera frugiperda to $\mathrm{Bt}$ maize and cotton varieties: implications for resistance management. Sci Rep. 6: 34864

Keeping MG, Kevedaras OL (2008) Silicon as a plant defence against insect herbivory: response to Massey, Ennos and Hartley. J. Anim Ecol 77: 631-633.

Lopes GS, Lemos RNS, Machado KKG, Maciel AAS, Ottati OLT (2008) Biologia de Spodoptera frugiperda (J. Smith)(Lepidoptera: Noctuidae) em folhas de mandioca (Manihot esculenta, Crantz). Caatinga. 21(3): 134-140.

Ma JF, Takahashi E (2002) Soil, Fertilizer, and Plant Silicon Research in Japan, Elsevier Science, Amsterdan, The Netherlands. Marcchner H (1995) Mineral nutrition of higher plants. New York: Academic, 889p.

Moraes ARA, Lourenção AL, Paterniani MEAGZ (2015) Resistance of conventional and isogenic transgenic maize hybrids to Spodoptera frugiperda (Lepidoptera: Noctuidae). Bragantia. 74(1): 50-57.

Nikpay A, Soleyman-Nejadian E, Goldasteh S, Farazimand H (2015) Response of Sugarcane and Sugarcane Stalk Borers Sesamia spp. (Lepidoptera: Noctuidae) to Calcium Silicate Fertilization. Neotrop Entomol 44: 498-503.

Omoto C, Bernardi O, Salmeron E, Sorgatto RJ, Dourado PM, Crivellari A. Carvalho RA, Willse A, Martinelli S, Head GP (2016) Field-evolved resistance to Cry1 Ab maize by Spodoptera frugiperda in Brazil. Pest Manag Sci. 72: 1727-1736.

Reynolds OL, Padula MP, Zeng R, Gurr GM (2016) Silicon: Potential to promote direct and indirect effects on plant defense against arthropod pasts in agriculture. Fron Plant Sci. 7:744.

Sosa-Gomez DR, Silva JJ (2010) Neotropical browstink bug (Echistus heros) resistance to methamidophos in Paraná, Brzil. Pesq Agopec Bras. 45: 767-769.

Souza PV, Machado BR, Freitas MM, Correa F, Almeida ACS, Jesus FG (2014) Chrysodeixis includens (Lepidoptera: Noctuidae) on a soybean trated with resistance inducers. Afr Jour Biotech. 13(50): 4562-4567.

Waquil JM, Villela FMF (2003). Gene bom. Rev Cultiv. 49: $.22-26$.

Xie Z, Song F, Xu H, Shao H, Song R (2014) Efects of silicon on photosynthetic characteristics of maize (Zea mays L.) on Alluvial Soil. The Sci World Jour. 2014:1-6.

Zancanaro PO, Buchweitz ED, Boiça Junior AL, Moro JR (2012) Avaliação de tecnologias de refúgio no cultivo de milho transgênico. Pesq Agropec Bras. 47(7): 886-891. 